\title{
ANALISA PEMBENGKOKAN PELAT DENGAN METODE LINE HEATING
}

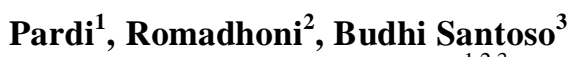 \\ Politeknik Negeri Bengkalis ${ }^{1,2,3}$ \\ pardi@polbeng.ac.id ${ }^{1}$
}

\begin{abstract}
One method of bending the plates in hull construction can be done either by conventional or by line heating method. The method of line heating has several advantages, such as lesser initial investment and can be used for three dimension form. This research is focused to obtain the relation between the parameter in line heating process and the conceited of plate curve that produced. With the aim of the curvature of structural changes caused by the heat given during the plate bending process it can be seen for the shipbuilding fabrication process. From the results of this study obtained data on line heating conditions on plates with a thickness of $10 \mathrm{~mm}$ (plates A and B) obtained the maximum curvature height is $11.1 \mathrm{~mm}$ at a heating speed of $8 \mathrm{~mm} / \mathrm{s}$ and a heating temperature of $3850 \mathrm{C}$. Furthermore, the amount of heat input that is applied to material 3327.47 Joules / sec and due to efficiency at 1697,001 Joules / sec.
\end{abstract}

Keyword: Line Heating Method, Line Heating Parameter, Curve Heights

Abstrak: Penelitian ini bertujuan untuk mendapatkan hubungan antara parameter-parameter dalam pengerjaan heat line bending dengan tinggi kelengkungan yang dihasilkan. Dengan pengujuan kelengkungan perubahan struktur yang disebabkan oleh panas yang diberikan selama proses pembengkokan pelat dapat diketahui untuk proses fabrikasi pembangunan kapal. Dari hasil penelitian ini diperoleh data-data kondisi line heating pada pelat dengan ketebalan $10 \mathrm{~mm}$ (pelat A dan B) didapatkan tinggi kelengkungan maksimal adalah 11,1 mm pada kecepatan pemanasan $8 \mathrm{~mm} / \mathrm{s}$ dan suhu pemanasan 3850 C. Selanjutnya besarnya masukan panas yang diberikan pada material 3327.47 Joule /det dan akibat efesiensi pads 1697.001 Joule/det.

Kata Kunci: Metode Line Heating, Parameter Line Heating, Tinggi Kelengkungan

\section{PENDAHULUAN}

Dari berbagai keterampilan yang dimiliki tenaga ahli pembangunan kapal pada sebuah galangan, kemampuan untuk membentuk lekukan sederhana maupun sulit pada pelat baja untuk bagian sisi luar lambung kapal adalah sebuah keahlian. Proses produksi ini sangat diperlukan, karena mesin pres bending atau rolling hanya dapat membentuk kelengkungan pelat yang sederhana saja.

Penggunaan mesin press bending atau rolling untuk membuat kelengkungan pada pelat membutuhkan pekerja yang keahlian atau komptensi khusus dan penggunaan peralatanperalatan berat secara terus-menerus. Kelengkungan pada pelat dapat dihasilkan dengan menggunakan penekanan (pressing), peening, atau dengan rollers. Meski cara-cara tersebut adalah teknik-teknik yang telah lazim digunakan, namun ada beberapa masalah, seperti dalam pembentukan pelat dengan penekanan/press yang sulit diprediksi bagaimana mendapatkan lekukan pelat sesuai dengan yang kita harapkan, dan juga pengerjaan proses peening dan rolling yang membuat pelat menjadi sedikit lebih tipis (Jacob, Kilduff, 1994).

Line heating adalah sebuah metode untuk membentuk pelat kelengkungan dengan menggunakan perlakuan panas secara lokal pada permukaan pelat. Metode ini digunakan sebagian pada industri galangan, dan banyak digunakan secara luas pada industri otomotif. Meski begitu proses ini sangat sulit untuk dikontrol, karena 
"seni" ini hanya dapat dilakukan oleh mereka yang sangat ahli dalam bidang tersebut. Permasalahannya adalah menyelidiki seberapa besar pengaruh variasi-variasi parameter line heating terhadap efek kelengkungan yang terjadi. Meski begitu, metode ini memiliki keuntungan sebab peralatan yang digunakan sangat murah yaitu dengan pengelasan oxyacetylene saja Qodir, Abdul, 2003).

Ketika suatu pelat diberi pemanasan setempat, dua hal yang terjadi: Pada daerah pelat dimana pemanasan dilakukan menjadi lebih lembut dan di saat yang sama mengembang. Kemudian pada daerah tersebut akan meregang. Karena pada daerah sekitarnya tetap maka peregangan pada daerah pemanasan seolah-olah terhambat oleh daerah sekitarnya dan mengalami beban tekan (compression) sedang daerah disekitarnya mengalami beban tarik (tension). Sebaliknya pada proses pendinginan, daerah pemanasan akan kembali mengalami penyusutan, tetapi sekali lagi penyusutan itu seolah-olah ditahan oleh daerah sekitarnya sehingga daerah pemanasan akan mengalami beban tarik dan daerah sekitarnya mengalami beban tekan. Urutan proses di atas diilustrasikan pada gambar 1.1

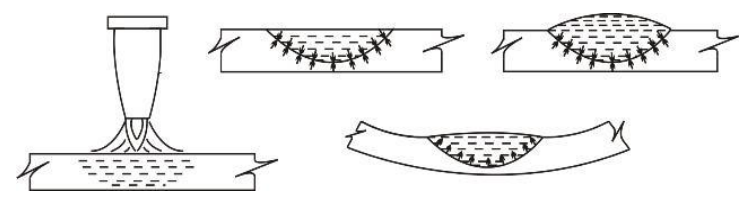

Gambar 1. Proses line heating

Secara umum, penulisan tugas akhir ini bertujuan untuk menyelidiki dan menganalisa proses dari metode pembengkokan pelat dengan line heating dan diharapkan akan diperoleh data-data kondisi line heating yang dapat digunakan pada proses pembengkokan pelat mulai dari bentuk yang sangat sederhana seperti bentuk silinder sampai dengan bentuk yang lebih rumit seperti bentuk bola, twisted, saddle dan pillow yang akan menunjang proses pabrikasi di industri galangan terutama untuk pembuatan radius bilga stern part kapal dan bulbous bow dan lain sebagainya.

\section{LANDASAN TEORI \\ Sifat-sifat thermal pelat}

Jika pada permukaan sebuah pelat diberi perlakuan panas setempat, pada pelat dimana dilakukan pemanasan tersebut akan menghasilkan tiga efek thermal: (1) pelat menyerap panas,

kemudian mengembang/meregang, dan (3) bagian pelat tersebut menyalurkan panas kedaerah pelat yang tidak langsung terkena sumber panas. Tiap efek tersebut memiliki sifat-sifat yang mengukur dan menggambarkan tingkatan efek yang terjadi. Absorpsi panas oleh permukaan pelat dikarakteristikkan sebagai sifat heat capacity $\left(c_{p}\right)$ yang spesifik dari pelat. Ekspansi biasanya digambarkan dengan coefficient of thermal expansion $(\alpha)$. Transmisi panas dikenal dengan thermal conductivity (k) (Jacob, James A \& Killduff, Thomas F, 1994).

\section{Heat capacity}

Efisiensi sebuah material untuk menyerap energi thermal dikenal dengan heat capacity. Heat capacity $\left(c_{p}\right)$ adalah jumlah joule yang dibutuhkan untuk menaikkan 1 unit massa (1 gram mol ) dari sebuah substansi $1 \mathrm{~K}$ pada tekanan konstan. Kebanyakan benda padat memiliki nilai $\left(c_{p}\right)$ yang hampir sama pada temperatur kamar. Jika kapasitas panas dari sebuah substansi dibandingkan dengan kapasitas panas dari air, maka dihasilkan specific heat dari sebuah substansi $(s)$. Nilai $c_{p}$ untuk air adalah 1 kalori/gram.${ }^{\circ} \mathrm{C}$ atau 4.184 
Joule/gram . ${ }^{\circ} \mathrm{C}$. Air adalah substansi yang membutuhkan pemakaian energi yang besar agar dapat menghasilkan perubahan dalam temperatur. Substansi dengan nilai-nilai specific heat yang tinggi tidak merubah temperaturnya dengan cukup besar. Dengan menggunakan satuan cal/g . k pada temperatur kamar, dapat dinyatakan specific heats (s) adalah: untuk silver, 0.06 ; iron, 0.1 ; glass, 0.14 ; dan polyethylene, $0.54 \quad$ (Engineering Materials Technology hal 161-165)

Sifat thermal yang lain, yaitu thermal mass, dalam hal heat capacity $\left(c_{p}\right)$ spesifik dinyatakan dengan persamaan: Thermal mass $=$ berat jenis ( $\rho) \mathrm{x}$ specific heat (s). hal ini memberikan sebuah indikasi panas yang dibutuhkan oleh sebuah unit volume dari material untuk mencapai temperatur yang telah ditentukan sebelumnya. Satuan dari thermal mass adalah $\mathrm{cal} / \mathrm{cm}^{3} .{ }^{\circ} \mathrm{C}$.

\section{Thermal expansion}

Hampir semua material padat mengembang ketika dipanaskan dan kemudian menyusut ketika didinginkan. Deformasi oleh panas ini dihasilkan dari terjadinya perubahan jarak antara atom-atom yang berdekatan akibat perubahan energi thermal. coefficient of thermal expansion $(\alpha)$ menggambarkan efek ini pada persamaan deformasi unit $(\varepsilon)$ di bawah ini:

$$
\varepsilon=\frac{\Delta l}{l \circ}=\alpha \Delta t
$$

Dimana $\Delta l$ adalah perubahan panjang dari dimensi tertentu, $l_{o}$ adalah panjang awal dari dimensi tersebut, dan $\Delta t$ adalah perubahan dalam temperatur. $\Delta l$ / $l_{o}$ juga digunakan untuk menyatakan deformasi unit $(\varepsilon$, regangan) yang dihasilkan perubahan temperatur. Satuan umumnya adalah $10^{-6}\left(\mathrm{~mm} / \mathrm{mm} \cdot{ }^{\circ} \mathrm{C}^{-1}\right)$. Untuk baja adalah, $\alpha=11.7 \times 10^{-6}{ }^{\circ} \mathrm{C}^{-1}$

\section{Thermal Conductivity}

Kemampuan zat padat non metalik untuk menyalurkan panas dikatakan adalah thermal conductivity. Thermal conductivity ini tergantung pada phonons ( quanta energi), yaitu partikel-partikel yang berperilaku seperti atom-atom gas dan menyalurkan getaran-getaran kisi-kisi zat padat dari tempat yang bertemperatur tinggi menuju ke tempat yang bertemperatur rendah. Phonon tersebut kemudian semakin bertabrakan saat bergerak pada pelat dengan kecepatan cahaya ketika temperatur semakin meningkat. Hal ini menghasilkan turunnya thermal conductivity pelat seiring meningkatnya temperatur.

Thermal conductivity $(k)$ adalah sebuah ukuran aliran panas yang melalui sebuah material. Hal tersebut berkaitan dengan aliran panas (aliran dari energi panas per unit area, per unit waktu) terhadap temperatur gradien, yang menyebabkan panas mengalir. Temperatur gradien $(\Delta t / \Delta d)$ menggambarkan perbedaan temperatur per unit jarak. Heat flow dapat dinyatakan dengan $q / A$, dimana $q$ mewakili energi panas dalam unit tertentu sebagai watts, atau kalori per detik $(\mathrm{cal} / \mathrm{s})$ dimana 1 watts $=4.1868$ $\mathrm{cal} / \mathrm{s}$; A adalah luas daerah yang dilalui panas, dalam satuan meter persegi. Perubahan temperatur dapat dinyatakan dalam satuan ${ }^{\circ} \mathrm{C}$, ${ }^{\circ} \mathrm{F}$, atau K. Dengan menggunakan simbol-simbol diatas, maka persamaan thermal conductivity dapat dituliskan

$$
\frac{\mathrm{q}}{\mathrm{A}}=\mathrm{k} \frac{\Delta \mathrm{t}}{\Delta \mathrm{d}}
$$

Dengan memasukkan satuan SI ke persamaan, satuan $k$ menjadi

$$
\mathrm{k}=\mathrm{W} /(\mathrm{m} . \mathrm{K})
$$




\section{Thermal resistance}

Material dengan sekat/insulate memiliki thermal conductivity yang rendah dan dapat memperlambat proses transfer dari panas. Thermal conductivity dari sebagian besar material tergantung pada temperatur. Dengan kata lain, nilainya berubah seiring perubahan temperatur. Sebaliknya, bahan-bahan seperti tekstil, gabus, dan lain-lain. memiliki thermal conductivity yang rendah karena bahan tersebut dapat memperangkap udara (Honeycombe, Badhesia, 1995).

\section{Perlakuan Panas terhadap Material}

Struktur kristal baja apabila dilakukan pemanasan dan pendinginan akan mengalami perubahan, dan perubahan yang terjadi akan bergantung pada tingginya suhu pada saat dipanaskan serta kecepatan pendinginan yang dilakukan. Dengan demikian pada sub bagian tentang perlakuan panas terhadap material, khususnya baja, ini akan dilakukan pembahasan tentang struktur baja karbon dan mekanisme perubahan struktur kristalnya, efek pemanasan yang dilakukan serta beberapa hal umum pada perlakuan panas terhadap baja (Sahri, Sofyan, 2015).

Pembahasan yang dilakukan tentang perlakuan panas terhadap material, dikhususkan pada material yang selanjutnya akan digunakan pada pengujian yaitu baja, dan pada pembahasan-pembahasan selanjutnya pun dikhususkan pada efek serta karakteristik baja secara umum.

\section{Struktur kristal dan perubahannya}

Telah diketahui bahwa atomatom pada logam menempati posisi tertentu relatif terhadap atom lain, maka dapat dikatakan bahwa atom logam tersusun secara teratur menurut suatu pola tertentu. Susunan atom-atom yang teratur dalam tiga dimensi menurut suatu pola tertentu dinamakan kristal. Bila ditarik garis-garis imajiner melalui inti-inti atom dalam suatu kristal maka akan diperoleh suatu kerangka tiga dimensi yang disebut space lattice (kisi ruang). Space lattice ini dapat dianggap tersusun dari sejumlah besar unit cell (sel satuan) yang merupakan bagian terkecil dari space lattice (Charles, 1996). Hal ini ditunjukkan oleh gambar di bawah ini (gambar 2.1):

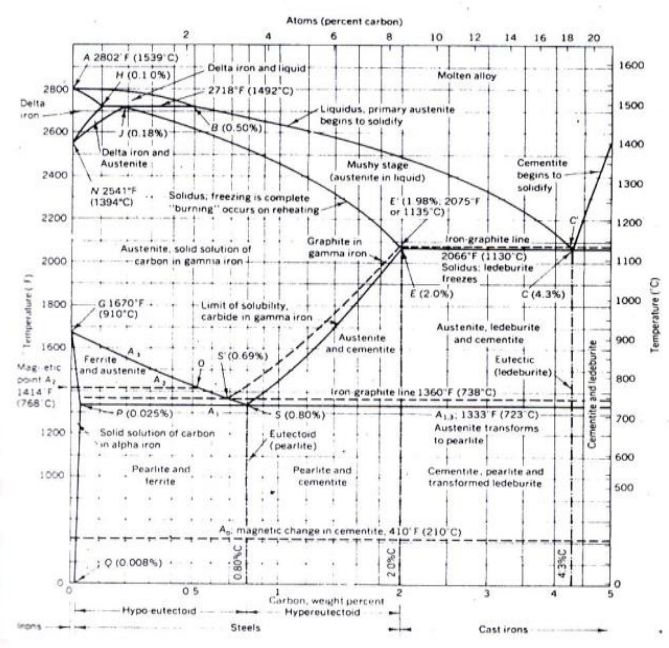

Gambar 2. Bagian dari Sebuah Space Lattice, dengan Sebuah Unit Cell ABCDEFGH

Ada 7 macam sistem kristal, yaitu cubic, tetragonal, orthorhombic, monoclinic, triclinic, hexagonal, dan rhombohedral.

Pada dasarnya senyawa antara besi dan karbon terbentuk oleh kristal besi dan kristal senyawa besi karbon $\left(\mathrm{Fe}_{3} \mathrm{C}\right)$ yang mana kedua kristal tersebut mempunyai 2 bentuk kristal allotrop, yaitu bentuk kristal baja berupa besi alpha dan karbida besi pada temperatur normal dan berupa besi gamma dan karbida besi pada temperatur yang lebih tinggi. Besi alpha dengan karbida besi membentuk campuran dua unsur pada temperatur normal, sedangkan karbida besi tersebut akan terlarut dalam besi gamma pada temperatur yang tinggi. Besi alpha lebih dikenal sebagai ferrite 
dan karbida besi yang bercampur dengannya dikenal sebagai cementite, sementara larutan karbida besi (cementite) dalam besi gamma dikenal sebagai austenite, dan campuran ferrite dengan cementite yang menyatu dikenal sebagai pearlite, yaitu bentuk-bentuk struktur kristal baja karbon yang terbentuk sesuai dengan fungsi temperatur serta kadar karbon yang terkandung (Prihadana, 1986). Hal tersebut digambarkan dalam diagram berikut ini:

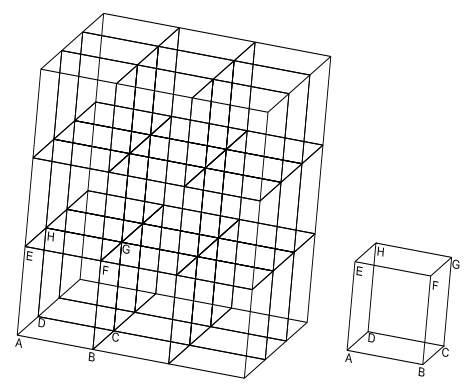

Gambar 3. Diagram Baja Karbon dengan Fungsi Suhu

Selain itu juga dikenal struktur kristal bainite dan martensite, yang selanjutnya akan sering dibicarakan. Struktur bainite terbentuk dari campuran ferrite dan cementite yang sulit dipisahkan, strukturnya sendiri mirip dengan martensite, tetapi mempunyai karakteristik yang sangat berbeda. Bainite terbentuk pada transformasi isothermal pada suhu antara $230^{\circ} \mathrm{C}$ sampai dengan $345^{\circ} \mathrm{C}$. Struktur martensite merupakan struktur baja karbon yang sangat keras dan kuat, berbentuk seperti jarum yang ujungnya tajam. Karena kerasnya maka struktur inipun sangat getas (brittle), meski pengaruh kadar karbonnya sangat berpengaruh (George D, 1986).

Dan seperti diketahui sebelumnya, karena sifat allotropi pada besi maka, bentuk latticenya berbeda pada temperatur berbeda. Pada temperatur kamar (besi alpha) dengan struktur Body Centre Cubic (BCC), pada temperatur antara $910{ }^{\circ} \mathrm{C}-1400$ ${ }^{\circ} \mathrm{C}$ (besi gamma) dengan struktur Face Centre Cubic dan di atas $1400{ }^{\circ} \mathrm{C}$ sampai mencair adalah besi delta. Bila temperatur kembali lagi maka struktur space lattice juga akan kembali seperti semula. Pada setiap kali terjadi perubahan ditandai dengan adanya pemberhentian penurunan temperatur (terlihat sebagai garis mendatar pada kurva pendinginan) untuk lebih jelasnya terlihat pada gambar berikut:

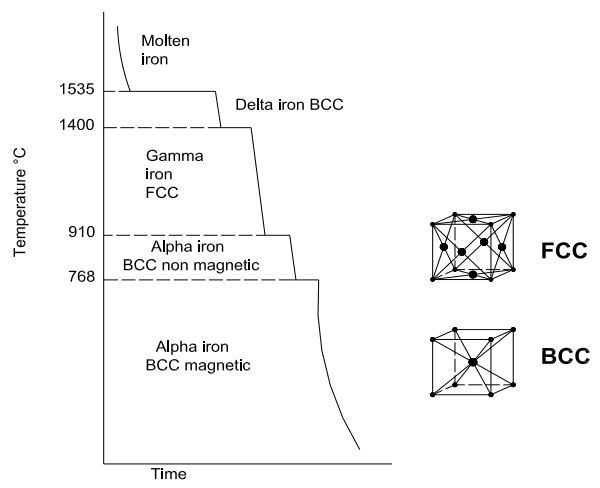

Gambar 4. Perubahan Bentuk Struktur Baja Akibat Pemanasan dan Pendinginan

Proses pembentukan maupun perbaikan akibat deformasi pada pelat lambung kapal, dilakukan dengan cara thermal ataupun mekanis. Hal ini dijelaskan pada diagram di bawah ini:

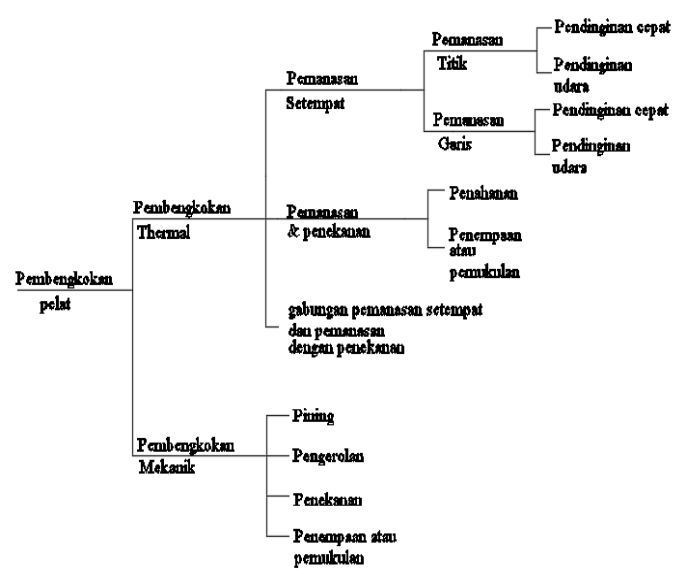

Gambar 5. Diagram Proses Pembengkokan Pelat dengan Cara Mekanis dan Thermal 
Heat line bending adalah cara membending dengan proses pengerjaan panas. Panas diterapkan menurut garis tertentu pada permukaan pelat dengan flame torch lalu didinginkan dengan air secara cepat / mendadak sehingga akan terjadi kontraksi permukaan dengan pelat terhadap area dan terjadilah deformasi Untuk pembengkokan pelat maupun perbaikan terhadap deformasi yang terjadi akibat proses pengelasan, biasanya pemanasan dilaksanakan dengan beberapa bermacam metode.

Bila suatu pelat baja dipanaskan sebagian, maka akan timbul tegangan pada pelat tersebut. Bila tegangan tersebut terkontrol maka adalah mungkin untuk menghasil kan regangan permanen seperti deformasi permanen, sama seperti bila dipakai gaya mekanis. Dengan prinsip yang sama maka tegangan akibat faktor termal dapat digunakan untuk menghasilkan regangan seperti distorsi. Disinilah terletak prinsip dasar proses pemanasan dan pendinginan yang terkontrol sehingga didapat suatu lengkungan tertentu pada pelat.

Pada proses line heating standar proses adalah penting terutama bila dikerjakan oleh tenaga yang kurang berpengalaman. Penentu utama derajat deformasi dan kelengkungan yang terjadi adalah faktor-faktor yang mengatur laju pemanasan dan pendinginan (Sahri, 2015), yakni:

Tipe dan ukuran ujung torch, Kecepatan jalan torch. Metode pendinginan (air/udara). Arus penerapan pendinginan. Jarak antara pusat pemanasan dan pusat pendinginan.

Dengan pertimbangan dari banyaknya tipe dan tebal material yang digunakan pada pembangunan kapal, maka anggapan bahwa kecepatan torch sebagai faktor utama adalah yang paling praktis. Dengan demikian bisa dibuat kombinasi-kombinasi yang dibutuhkan dari faktor-faktor yang lain.

\section{METODE PENELITIAN}

Secara ringkas guna memperoleh data-data yang diperlukan dalam rangka menyelesaikan penelitian ini, dilakukan proses pembengkokan pelat dengan line heating.

\section{Proses Pembengkokan Pelat dengan Line Heating}

Peralatan yang digunakan dalam proses pembengkokan pelat dengan line heating adalah: Jig penyangga pelat, Peralatan las oxy-acytelene, Selang air, Gelas ukur 1 liter, Thermo kopple, Stop watch, Sarung tangan, Penitik.

\section{Persiapan pembengkokan dengan line heating}

Sebelum dilakukan proses line heating dilakukan langkah-langkah persiapan antara lain:

Menyediakan semua peralatan yang dibutuhkan. Menandai benda uji pertama dengan 3 garis pemanasan tiap pelatnya, dengan jarak antar garis 100 $\mathrm{mm}$. Hal ini ditunjukkan pada sketsa di bawah ini:

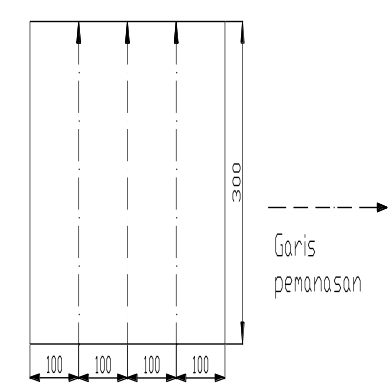

Gambar 6. Penandaan untuk Proses Line Heating pada Benda Uji 1

Benda uji kedua ditandai sama seperti benda uji pertama dengan jarak antar garis $125 \mathrm{~mm}$. Tiap garis pemanasan dibagi menjadi 5 daerah interval, dengan jarak antar interval 100 mm. Pembagian interval ini ditujukan untuk mengukur kecepatan jalan torch secara lebih spesifik dan menganalisa dampak faktor kecepatan pemanasan 
terhadap deformasi yang terjadi pada pelat. Hal ini dapat dilihat pada sketsa di bawah ini:
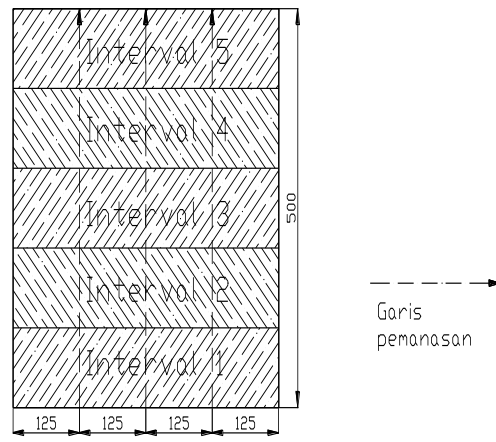

Gambar 7. Penandaan untuk Proses Line Heating pada Benda Uji 2

Benda uji ditata di atas jig dengan kondisi tepinya bebas tidak diapit dan disiapkan sedemikian rupa sehingga tidak berubah posisinya.

Mengukur laju air pendinginan dengan menampungnya di dalam gelas ukur, kemudian mengukur waktunya.

Selang air diatur dan ditempatkan sedemikian sehingga air dapat mengalir dengan bebas dan tetap konstan.

Tempat pengujian diadakan di luar ruangan, dengan tujuan memudahkan pembuangan air yang telah digunakan dalam proses line heating, dengan pertimbangan tidak akan mempengaruhi parameterparameter pengujian line heating yang sebelumnya telah ditetapkan.

\section{Proses pembengkokan dengan line heating}

Untuk proses line heating ini dilakukan beberapa variasi-variasi parameter yang berpengaruh dengan efek lengkungan yang akan terjadi. Parameter-parameter yang diperhatikan pada pengujian line heating ini adalah:

Penggunaan mata bakar (torch) disesuaikan dengan ketebalan pelat

Parameter jumlah panas yang masuk didapatkan dengan melakukan pemanasan dengan berbagai kecepatan variasi.

Metode pendinginan pada proses ini memakai pendinginan air atas dan langsung dengan selang biasa. Selang air diposisikan $\pm 5 \mathrm{~cm}$ di belakang torch dan seiring torch mulai berjalan maka selang air mengikuti.

Laju pendinginan pada pengujian ini divariasikan dengan mengatur besar kecilnya air yang keluar dari kran.

Setelah proses pemanasan dilaksanakan dengan memperhatikan parameter-parameter di atas, maka diamati kembali sejauh mana hasil proses tersebut pada kerataan pelat dengan cara seperti yang telah dilakukan sebelumnya.

\section{Jumlah panas yang diterima benda uji} diterima permukaan pada saat pemanasan dengan menggunakan brander tidak hanya tergantung pada faktor koeffisien serta keadaan pemanasan yang merupakan dasar perpindahan kalor secara konveksi, tetapi juga mempunyai spesifikasi efektifitas sendiri yang mana dipengaruhi oleh besarnya aliran gas pembakar, dan koeffisisen konsentrasi yang merupakan fungsi jarak, seperti yang dapat dilihat pada tabel berikut:

Tabel 1. Karakteristik Thermal untuk Nyala Api Oksi-Asetilin dengan Mata Bakar Tunggal.

\begin{tabular}{|c|c|c|c|c|c|c|c|}
\hline $\operatorname{Tip}_{\text {size }}$ & $\begin{array}{c}\text { Orifitce } \\
\text { diameter, } \\
\text { mm }\end{array}$ & $\begin{array}{l}\text { Acetylene } \\
\text { flow, lit } \\
\text { per hr }\end{array}$ & $\begin{array}{c}\text { Inner fone } \\
\text { length, } \\
\text { mans }\end{array}$ & $\begin{array}{l}\text { Effective } \\
\text { heat Input, } \\
q . \text { caljsec }\end{array}$ & $\begin{array}{l}\text { E'ficlency, } \\
\text { per cent }\end{array}$ & $\begin{array}{c}\text { Concen- } \\
\text { tratlon } \\
\text { caefficient. } \\
k, \mathrm{l} / \mathrm{Cm}\end{array}$ & 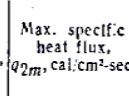 \\
\hline 1 & 1.0 & 150 & 9 & 380 & 72 & 0.39 & 47 \\
\hline 2 & 1.3 & 250 & 10 & 600 & 68 & 0.35 & 67 \\
\hline 3 & 1.6 & 400 & 11 & 720 & 51 & 0.31 & 72 \\
\hline 4 & 2.0 & 600 & 12 & 920 & 44 & 0.28 & 82 \\
\hline 5 & 2.5 & 1,000 & 14 & 1,270 & 36 & 0.23 & 93 \\
\hline 6 & 3.0 & 1,700 & 15 & 1,750 & 29 & 0.20 & 111 \\
\hline 7 & 3.5 & 2,600 & 17 & 2,250 & 25 & 0.17 & 122 \\
\hline
\end{tabular}


Secara grafis, yang dikaitkan dengan kemungkinan adanya pengaruh sudut kemiringan mata bakar (torch) terhadap jumlah panas yang diterima permukaan pelat, maka aliran panas spesifik yang terjadi dapat dilihat pada gambar di bawah ini:

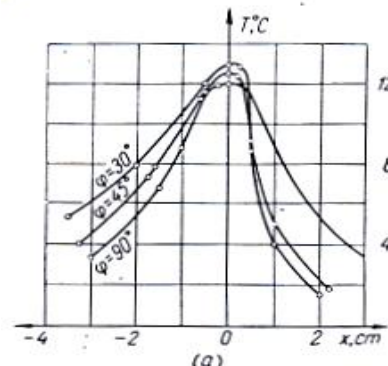

(a)

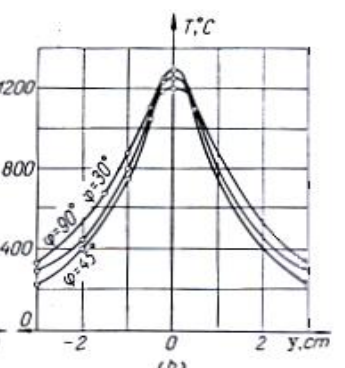

(0)
Fig. 57. Temperature gradient in sheet metal at the end of a short heat-

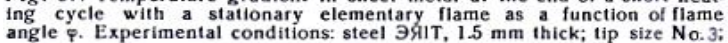
oxygen-to-acetylene ratio $\beta_{0}=1.15 ; L=10.5 \mathrm{~mm} ; h=\frac{5}{4} L=13 \mathrm{~mm}$; (a) along axls $O X$ heating time $3 \mathrm{sec}$

(a) along axis $O X$ (projection of the flame on the sheet): (b) along

Gambar 8. Karakteristik aliran panas spesifik

\section{HASIL PENELITIAN}

Sesuai dengan proses line heating yang dilakukan terhadap benda uji selama penelitian, dapat dihasilkan data-data yang diperlukan untuk dianalisa guna menunjukkan adanya perubahan-perubahan yang terjadi.

Faktor suhu / temperatur sebagai salah satu faktor penentu derajat deformasi / kelengkungan yang terjadi

Tabel 3. Pengukuran Kerataan Benda Uji 1 setelah Pemanasan Garis (Pelat A)

\begin{tabular}{|c|c|c|c|c|c|c|c|}
\hline & & & & PELAT A & & & \\
\hline $\begin{array}{c}\text { Jarak } \\
(\mathrm{cm})\end{array}$ & $\mathrm{X}_{1}$ & $\mathrm{X}_{2}$ & $\mathrm{X}_{3}$ & $\mathrm{X}_{4}$ & $\mathrm{X}_{5}$ & $\mathrm{X}_{6}$ & $\mathrm{X}_{7}$ \\
\hline $\mathrm{Y}_{1}$ & 0 & 1,25 & 2,49 & 4,06 & 2,50 & 1,28 & 0 \\
\hline $\mathrm{Y}_{2}$ & 0 & 1,28 & 2,50 & 4,08 & 2,52 & 1,30 & 0 \\
\hline $\mathrm{Y}_{3}$ & 0 & 1,15 & 2,76 & 4,31 & 2,79 & 1,18 & 0 \\
\hline $\mathrm{Y}_{4}$ & 0 & 1,35 & 2,77 & 4,84 & 2,80 & 1,38 & 0 \\
\hline $\mathrm{Y}_{5}$ & 0 & 1,15 & 2,74 & 4,99 & 2,78 & 1,19 & 0 \\
\hline $\mathrm{Y}_{6}$ & 0 & 1,00 & 2,51 & 5,21 & 2,54 & 1,02 & 0 \\
\hline $\mathrm{Y}_{7}$ & 0 & 0,97 & 2,51 & 5,34 & 2,50 & 0,98 & 0 \\
\hline
\end{tabular}

tidak dapat dihitung, dikarenakan keterbatasan peralatan pengukur yang digunakan. Thermo kopel yang digunakan ternyata tidak dapat mengukur suhu permukaan pelat dengan cepat, dan posisi pengukurannya tidak dapat dilakukan pada posisi yang diinginkan.

\section{Analisa Proses Line Heating}

Tabel 2. Pengukuran kerataan benda uji 1 sebelum pemanasan garis (pelat A, B)

\begin{tabular}{|l|c|c|c|c|c|c|c|c|c|}
\hline & & & & & $\begin{array}{c}\text { PELAT } \\
\text { A,B }\end{array}$ & & & & \\
\hline Jarak (cm) & $X_{1}$ & $X_{2}$ & $X_{3}$ & $X_{4}$ & $X_{5}$ & $X_{6}$ & $X_{7}$ & $X_{8}$ & $X_{9}$ \\
\hline$Y_{1}$ & 0,10 & 0,2 & 0,4 & 0,2 & 0,5 & 0,2 & 0,1 & 0,1 & 0,1 \\
\hline$Y_{2}$ & 0,2 & 0,1 & 0,4 & 0,5 & 0,5 & 0,2 & 0,1 & 0,2 & 0,2 \\
\hline$Y_{3}$ & 0,1 & 0,2 & 0,4 & 0,5 & 0,2 & 0,1 & 0,1 & 0,5 & 0,2 \\
\hline$Y_{4}$ & 0,3 & 0,4 & 0,8 & 0,8 & 0,2 & 0,3 & 0,3 & 0,4 & 0,2 \\
\hline$Y_{5}$ & 0,3 & 0,5 & 0,7 & 0,9 & 0,1 & 0,5 & 0,3 & 0,3 & 0,7 \\
\hline$Y_{6}$ & 0,3 & 0,5 & 0,2 & 0,9 & 0,3 & 0,5 & 0,3 & 0,2 & 0,2 \\
\hline$Y_{7}$ & 0,1 & 0,5 & 0,1 & 0,8 & 0,3 & 0,5 & 0,1 & 0,4 & 0,1 \\
\hline
\end{tabular}

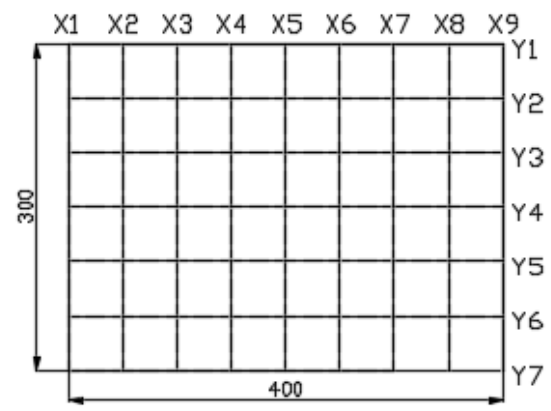

Gambar 9. Keadaan Awal Pelat Uji 1 dan 2

Tabel 4. Pengukuran kerataan benda uji 1 setelah pemanasan garis (pelat B)

\begin{tabular}{|c|c|c|c|c|c|c|c|}
\hline & & & & \multicolumn{3}{|c|}{ PELAT B } & \\
\hline $\mathrm{NO}$ & $\mathrm{X}_{1}$ & $\mathrm{X}_{2}$ & $\mathrm{X}_{3}$ & $\mathrm{X}_{4}$ & $\mathrm{X}_{5}$ & $\mathrm{X}_{6}$ & $\mathrm{X}_{7}$ \\
\hline $\mathrm{Y}_{1}$ & 0 & 3,63 & 7,16 & 11,13 & 7,16 & 3,63 & 0 \\
\hline $\mathrm{Y}_{2}$ & 0 & 3,48 & 7,03 & 10,83 & 7,03 & 3,48 & 0 \\
\hline $\mathrm{Y}_{3}$ & 0 & 3,33 & 6,90 & 10,53 & 6,90 & 3,33 & 0 \\
\hline $\mathrm{Y}_{4}$ & 0 & 3,18 & 6,40 & 10,28 & 6,40 & 3,18 & 0 \\
\hline $\mathrm{Y}_{5}$ & 0 & 3,19 & 6,23 & 9,94 & 6,23 & 3,19 & 0 \\
\hline$Y_{6}$ & 0 & 3,17 & 6,25 & 9,80 & 6,25 & 3,17 & 0 \\
\hline $\mathrm{Y}_{7}$ & 0 & 3,18 & 6,24 & 9,65 & 6,24 & 3,18 & 0 \\
\hline
\end{tabular}




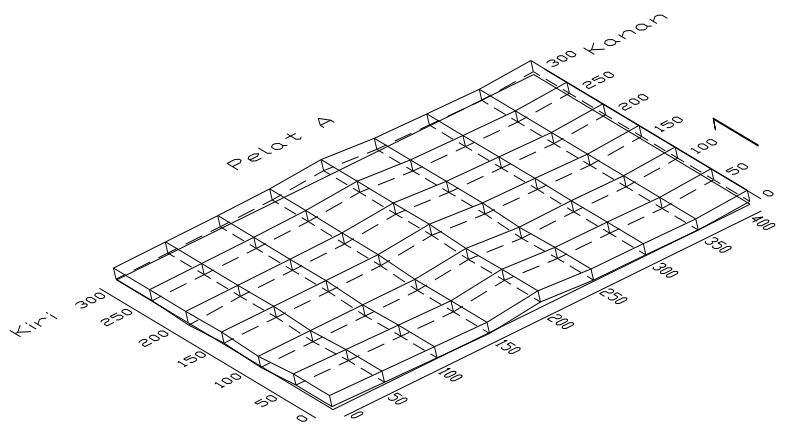

Gambar 10. Pelat A setelah Pemanasan Garis

Terjadi dua macam deformasi atau perubahan kelengkungan pada permukaan pelat menurut arah kelengkungannya, yaitu kelengkungan ke atas dan ke bawah. Hal ini dapat dilihat pada gambar 10 dan gambar 11 .

Dari gambar 10 terlihat bahwa pada waktu pemanasan berlangsung, sisi A pelat akan mendapat tegangan ke arah luar dan sisi B pelat akan mendapat tegangan ke arah dalam (1). Akibatnya setelah pemanasan selesai, seolah-olah pelat akan melengkung ke atas (2). Pada waktu proses pendinginan berlangsung, sisi A pelat ganti mendapat tegangan yang arahnya ke dalam dan sisi $B$ pelat mendapat tegangan yang arahnya ke luar (3). Akibatnya setelah proses pendinginan selesai, pelat akan melengkung ke bawah (4)

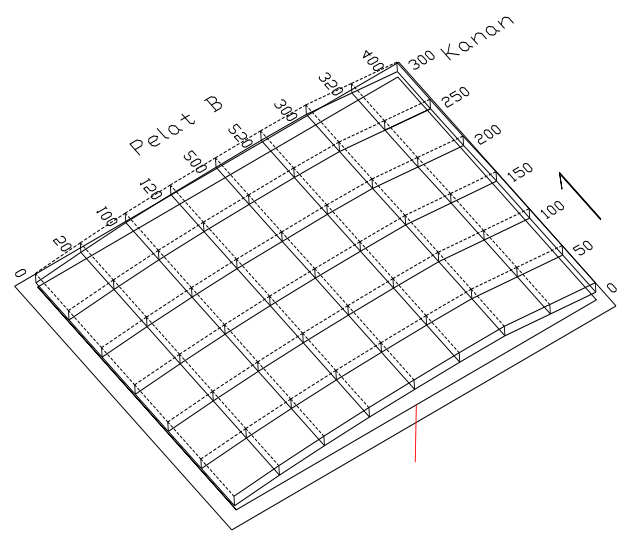

Gambar 11. Pelat B setelah Pemanasan Garis
Dari gambar 10 terlihat bahwa pada waktu pemanasan berlangsung, sisi A pelat akan mendapat tegangan ke arah luar dan sisi B pelat akan mendapat tegangan ke arah dalam (1). Akibatnya setelah pemanasan selesai, seolah-olah pelat akan melengkung ke atas (2). Pada waktu proses pendinginan berlangsung, sisi A pelat ganti mendapat tegangan yang arahnya ke dalam dan sisi B pelat mendapat tegangan yang arahnya ke luar (3), namun karena laju pendinginan yang cepat sekali sehingga atom-atom yang menyusun ikatan logam pada pelat tidak cukup memiliki energi untuk bergerak dan mencari/mengatur kedudukannya relatif terhadap atom lain untuk membentuk inti-inti kristal yang baru.

Sesuai dengan pengujian maka didapatkan hubungan antara Variasi kecepatan pemanasan pada pelat A, B, dengan tinggi kelengkungan yang terjadi. Hasil dapat dilihat pada tabel dibawah ini:

Tabel 5. Hubungan Kecepatan, Tinggi Kelengkungan, dan Suhu Pengujian

\begin{tabular}{|c|c|c|c|c|c|c|c|c|c|}
\hline & \multicolumn{3}{|c|}{ Kecepatan $(\mathrm{m} / \mathrm{s})$} & \multicolumn{3}{|c|}{ Tingag kelengkungan (mm } & \multicolumn{3}{|c|}{ Suhu (derajat celcus) } \\
\hline & Kin & tengah & an & Kiri & Tengah & Kanan & $k_{\text {in }}$ & & 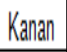 \\
\hline & 0,0083 & 0,011 & 0,00820 & 01,35 & , & 1,38 & 185 & 246.7 & 10 \\
\hline Pelat B & 0,00730 & 0,00810 & 0,00710 & 3,6 & 11,1 & 3,71 & 2089 & 385 & 210 \\
\hline
\end{tabular}

Tinggi kelengkungan yang diambil adalah tinggi kelengkungan pada daerah yang dikenai pemanasan langsung dan merupakan koordinat yang memiliki harga kelengkungan yang tertinggi untuk jalur pemanasannya. Kecepatan pemanasan dan suhu pengujian diambil pada saat $1 \mathrm{x}$ pemanasan. Grafik hubungan tinggi kelengkungan dengan kecepatan pemanasan dan suhu pengujian. 


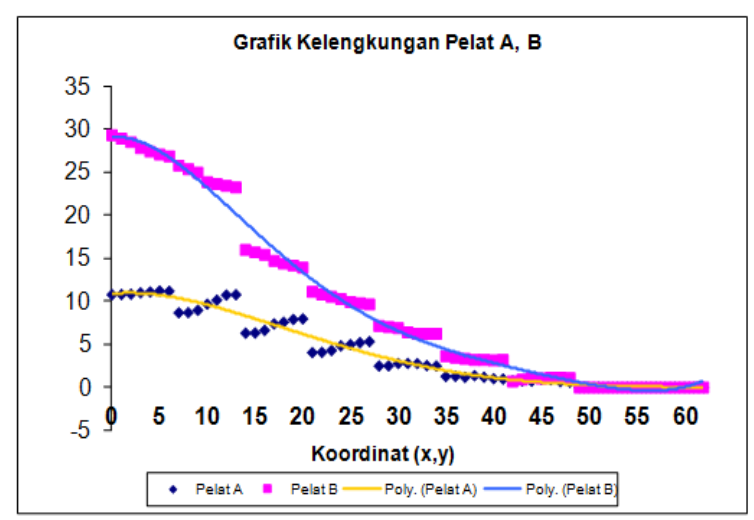

Grafik Tinggi Kelengkungan VS Koordinat Pelat A, B

\section{Perhitungan Jumlah Panas yang Diterima saat Pemanasan Garis}

Untuk menghitung jumlah panas yang diterima pelat pada saat dilakukan pemanasan dengan brander, faktorfaktor yang berpengaruh adalah:

Ukuran mata bakar, digunakan No. 3 A dengan diameter lubang 1,6 mm. Perbandingan campuran gas oksigen dan asetilin, digunakan ratio 1,0 (tekanan gas oksigen dan asetilin 2,5 bar). Jarak antara ujung mata bakar dengan permukaan pelat, diukur saat pemanasan sebesar $\pm 10 \mathrm{~mm}$. Ketebalan pelat yang digunakan $5 \mathrm{~mm}$ dan $10 \mathrm{~mm}$

Posisi mata bakar, tegak lurus dengan permukaan pelat. Kecepatan pemanasan, sesuai dengan data. Lama pemanasan, sesuai dengan data.

Dari data di atas dapat dilihat pada tabel 2 yang merupakan hasil penelitian dengan kondisi yang sama adalah:

Ukuran mata bakar $=3$

Diameter lubang $\quad=1.6 \mathrm{~mm}$

Aliran asetilin $\quad=400$ liter/ jam

Panjang busur dalam $=11 \mathrm{~mm}$

Masukan panas efektif $=720 \mathrm{kalori} / \mathrm{S}$

Efisiensi $\quad=51$ persen

Koefisien konsentrasi $=0.31 / \mathrm{cm}$

Aliran panas spesifik maksimum = 72 kalori / $\mathrm{cm}^{2}$. detik
Besar masukan panas dikoreksi untuk perbandingan jarak ujung mata bakar pada permukaan pelat (h) dengan panjang busur dalam (L), yaitu:

$\mathrm{h} / \mathrm{L}=10 / 11=0.9$

Dengan menggunakan grafik sebagai berikut:

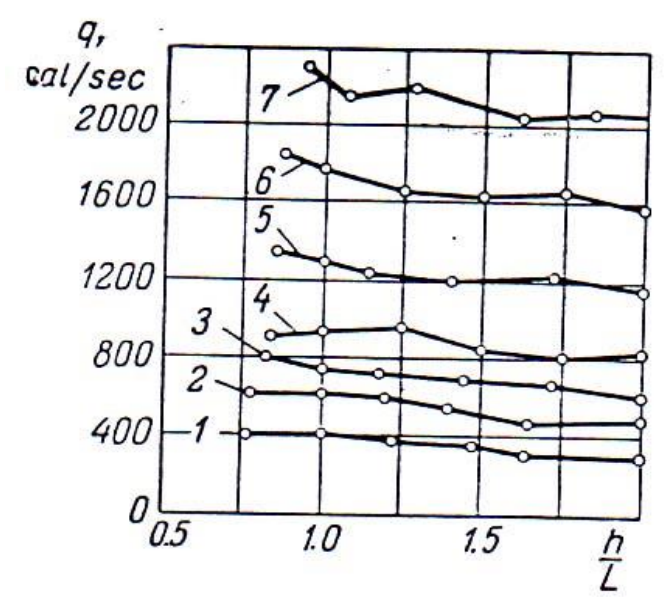

Gambar 12. Grafik Masukan Panas Efektif sebagai Fungsi Rasio Ukuran Mata Bakar Torch

Didapat besar masukan panas sebesar $795 \mathrm{kal} / \mathrm{det}$. Masukan panas $615 \mathrm{kal} / \mathrm{det}=795 \times 4.1855$ $=3327.47$ Joule $/$ det

Akibat efisiensi panas $=51 \quad \% \quad \mathrm{x}$ $3327.47=1697.001$ Joule $/ \mathrm{det}$

\section{PEMBAHASAN}

Penggunaan mesin press bending atau rolling untuk membuat kelengkungan pada pelat membutuhkan pekerja yang keahlian atau komptensi khusus dan penggunaan peralatanperalatan berat secara terus-menerus. Kelengkungan pada pelat dapat dihasilkan dengan menggunakan penekanan (pressing), peening, atau dengan rollers. Meski cara-cara tersebut adalah teknik-teknik yang telah lazim digunakan, namun ada beberapa masalah, seperti dalam pembentukan pelat dengan penekanan/press yang sulit diprediksi bagaimana mendapatkan lekukan pelat sesuai dengan yang kita harapkan, dan juga pengerjaan proses 
peening dan rolling yang membuat pelat menjadi sedikit lebih tipis.

Line heating adalah sebuah metode untuk membentuk pelat kelengkungan dengan menggunakan perlakuan panas secara lokal pada permukaan pelat. Metode ini digunakan sebagian pada industri galangan, dan banyak digunakan secara luas pada industri otomotif. Meski begitu proses ini sangat sulit untuk dikontrol, karena "seni" ini hanya dapat dilakukan oleh mereka yang sangat ahli dalam bidang tersebut. Permasalahannya adalah menyelidiki seberapa besar pengaruh variasi-variasi parameter line heating terhadap efek kelengkungan yang terjadi. Meski begitu, metode ini memiliki keuntungan sebab peralatan yang digunakan sangat murah yaitu dengan pengelasan oxyacetylene saja.

Heat line bending adalah cara membending dengan proses pengerjaan panas. Panas diterapkan menurut garis tertentu pada permukaan pelat dengan flame torch lalu didinginkan dengan air secara cepat / mendadak sehingga akan terjadi kontraksi permukaan dengan pelat terhadap area dan terjadilah deformasi Untuk pembengkokan pelat maupun perbaikan terhadap deformasi yang terjadi akibat proses pengelasan, biasanya pemanasan dilaksanakan dengan beberapa bermacam metode.

Bila suatu pelat baja dipanaskan sebagian, maka akan timbul tegangan pada pelat tersebut. Bila tegangan tersebut terkontrol maka adalah mungkin untuk menghasil kan regangan permanen seperti deformasi permanen, sama seperti bila dipakai gaya mekanis. Dengan prinsip yang sama maka tegangan akibat faktor termal dapat digunakan untuk menghasilkan regangan seperti distorsi. Disinilah terletak prinsip dasar proses pemanasan dan pendinginan yang terkontrol sehingga didapat suatu lengkungan tertentu pada pelat.
Pada proses line heating standar proses adalah penting terutama bila dikerjakan oleh tenaga yang kurang berpengalaman. Penentu utama derajat deformasi dan kelengkungan yang terjadi adalah faktor-faktor yang mengatur laju pemanasan dan pendinginan (Sahri, 2015), yakni:

Tipe dan ukuran ujung torch, Kecepatan jalan torch. Metode pendinginan (air/udara). Arus penerapan pendinginan. Jarak antara pusat pemanasan dan pusat pendinginan.

\section{SIMPULAN}

Proses line heating pada pelat dengan ketebalan $10 \mathrm{~mm}$ (pelat A dan B) didapatkan tinggi kelengkungan maksimal adalah 11,1 $\mathrm{mm}$ pada kecepatan pemanasan $8 \mathrm{~mm} / \mathrm{s}$ dan suhu pemanasan $385^{\circ} \mathrm{C}$.

Besarnya masukan panas yang diberikan pada material 3327.47 Joule / det dan akibat efesiensi pads 1697.001 Joule / det

\section{DAFTAR PUSTAKA}

Charles, K. (1996). Introduction to Solid State Physics. 6th Edition. John Wiley \& Sons, Inc

George, E. (1986). Mechanical Metallurgy, Third edition, McGraw-Hill, Inc. New York

Hendroprasetyo, A. P., Wing, W., Soeweify, S. (2003). Laporan Akhir Hibah Pengajaran Modul Ajar, Inspeksi Las. Institut Teknologi Sepuluh Nopember Surabaya

Honeycombe, R. W. K., \& Badhesia, H. K. D. H. (1995). STEELS, Microstructure and Properties, Second edition, Edward Arnold, a Division of Hodder Headline PLC, London

Jacob, J. A., \& Killduff, T. F. (1994). Engineering Materials Technology, Prentice Hall International Editions 
Prihadana, D. (1986). Pengaruh Jumlah Panas pada Proses Perbaikan Deformasi Pelat dengan Cara Line Heating. Institut Teknologi Sepuluh Nopember, Surabaya

Qodir, A. (2003). Analisa Pengaruh Pemanasan terhadap Struktur Base Metal Material. Institut Teknologi Sepuluh Nopember, Surabaya

Sahri, S. (2015). Analysis of the Effect Line Heating on Mechanical Properties and Microstructure of Steel ASTM A36 with Variations Cooling. Department of Naval Architecture and Shipbuilding Engineering ITS Surabaya 